\title{
Sex and the City (Comedy): Moll Cutpurse, Carrie Bradshaw, and the Power of the Feminist (?) Purse
}

Celia R. Daileader

\section{(2) OpenEdition}

\section{Journals}

\section{Electronic version}

URL: http://journals.openedition.org/shakespeare/1603

DOI: 10.4000/shakespeare.1603

ISSN: 2271-6424

\section{Publisher}

Société Française Shakespeare

Printed version

Date of publication: 1 March 2011

Number of pages: $55-66$

ISBN: 2-9521475-7-4

\section{Electronic reference}

Celia R. Daileader, «Sex and the City (Comedy): Moll Cutpurse, Carrie Bradshaw, and the Power of the Feminist (?) Purse », Actes des congrès de la Société française Shakespeare [Online], 28 | 2011, Online since 15 February 2011, connection on 01 May 2019. URL : http://journals.openedition.org/ shakespeare/1603 ; DOI : 10.4000/shakespeare.1603 


\section{Shakespeare et la Cité}

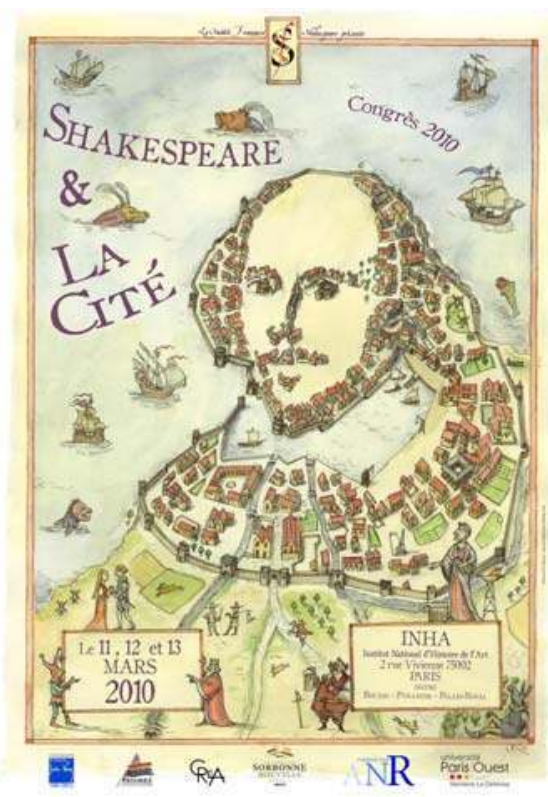

actes du Congrès

organisé par la

SOCIÉTÉ FRANÇAISE SHAKESPEARE

les 11,12 et 13 mars 10

textes réunis par

Pierre KAPITANIAK

sous la direction de

Dominique GoY-BLANQUET 
COUVERTURE :

Edouard Lekston 2010

conception graphique et logo

Pierre Kapitaniak

\section{(C) 2011 Société Française Shakespeare Institut du Monde Anglophone} Université de Paris III - Sorbonne Nouvelle 5 rue de l'École de Médecine 75006 Paris

www.societefrancaiseshakespeare.org réservés pour tous les pays 


\title{
SEX AND THE CITY (COMEDY): Moll Cutpurse, Carrie Bradshaw, AND The Power of THe Feminist (?) PURSE
}

\author{
Celia R. DAILEADER
}

Cet article cherche à mettre à l'épreuve - par le biais d'un anachronisme stratégique - la nostalgie féministe provoquée par l'héroïne de The Roaring Girl de Thomas Middleton et Thomas Dekker, en la confrontant aux protagonistes féminines de la série culte de Sex and the City. Cette approche diachronique permettra d'apporter un éclairage à la fois au genre de la comédie urbaine et à la culture populaire féminine contemporaine, surtout en ce qui concerne les rapports que ces deux genres entretiennent avec la société de consommation et avec l'idéologie sexuelle.

This paper aims to test-by way of strategic anachronism—-the feminist nostalgia provoked by Thomas Middleton and Thomas Dekker's heroine in The Roaring Girl by pitting her against the female characters at the center of the cult of Sex and the City. This diachronic approach will shed light both on the genre of early modern city comedy and on contemporary women's popular culture, particularly in these genres' relationships to consumerism and sexual ideology.

$\mathrm{P}$

icture a woman shopping. Mincing along in her high heels on Fifth Avenue or Covent Garden or les Champs Élysées, purse bobbing on her elbow, gaudy bags clutched in her fists. It is an image that gluts contemporary popular culture. But let's think outside the box-or rather the Gucci bag. Let's think back and out of our postfeminist complacency. Virginia Woolf wrote in A Room of One's Own: "It is a fact that still takes my breath away-the power of my purse to breed ten-shilling notes automatically. I open it and there they are." ${ }^{1}$ If that experience was novel in 1928, how much more so in early modern England, when women wielded neither the power of the pen, nor of the purse, when a married woman had no legal recourse if her husband squandered every penny of her portion. Picture a woman shopping on the streets of London in 1609. That takes more imagination. Unless you've read Thomas Middleton and Thomas Dekker's The Roaring Girl.

Feminist scholars from Woolf onwards have brought Renaissance literature fruitfully in dialogue with women's fiction. This critical inheritance has made possible (for example) Laurie Osborne's work on romance novels and Shakespeare, itself a sub-set of the now-

${ }^{1}$ Virginia Woolf, A Room of One's Own, in The Longman Anthology of Women's Literature, ed. Mary K. DeShazer (New York, Addison-Wesley, 2001), p. 33. 
burgeoning field of appropriation studies. As of yet, though, the current debates on so-called "chick-lit" (and its cinematic corollary of "chickflicks") seem not to have effected feminist analysis of early modern drama. Yet "chick-lit"-a genre owing its existence to novels such as Helen Fielding's Bridget Jones's Diary, Sophie Kinsella's Confessions of a Shopaholic, and Candace Bushnell's Sex and the City-is a genre that stands poised to eclipse romance in popularity among women readers of the post-Cosmo generation. And the Shakespeareanisms of the classic dime-store bodice-rippers-many of which are (as one romance novelist has stated) variations on A Taming of the Shrewappear in new incarnations in chick-lit and the films based on those novels.

But I do not want to talk, today, about Shakespeare. I want to talk about the dramatist that Gary Taylor has boldly dubbed "our other Shakespeare." And though the title of our conference aligns the topic la cité with the Bard of Avon, the Bard himself cannot be credited with mastering the city comedy. This paper aims to test-by way of strategic anachronism-the feminist nostalgia provoked by Middleton and Dekker's cross-dressing, leonine stage heroine, by pitting her against those much-touted "cougars" at the center of the cult of Sex and the City. Speaking of this as a "cult" allows me to address simultaneously the best-selling novel, the popular cable-TV series, and the film by that name (though I will also at times distinguish these three). This diachronic approach should help me to shed light both on the genre of early modern city comedy and on contemporary women's popular culture, particularly in these genres' relationships to consumerism and sexual ideology. Ultimately, we may even wind up with a subtle lesson about Shakespeare. Feminist intellectuals dismayed and distracted by the film's insultingly pervasive product placement may miss the uncannily Shakespearean tint to its alleged happy ending. Carrie-like Katherina Minola in Shrew-is humiliated on her wedding-day. Carrie dons the white poofy dress and makes herself a laughing-stock. Carrie thinks she can have it both ways-marry a man who calls himself Mr. Big and keep her dignity. She could have taken a few lessons from Moll Cutpurse.

\footnotetext{
${ }^{2}$ Gary Taylor and John Lavagnino, eds., Thomas Middleton : The Collected Works (Oxford, Clarendon Press, 2007), p. 58.
} 
According to Coppelia Kahn, "The Roaring Girl dramatizes the interdependency of fashion, money, gender and rank that is a major preoccupation of city comedy." Kahn makes the point that the first scene of the play-establishing the romantic plot of paternal class-pride thwarting young love-"superimposes the working woman who makes and sells commodities onto the bourgeois woman who is herself a commodity"-the latter embodied by the shop-wives from whom the play's heroine buys tobacco and clothes. ${ }^{3}$ Moll stands in an ambiguous relation to this class binary, in the same way that her masculine dress and behaviors thwart dichotomous thinking about gender. And her sexual and class ambiguity complicate her relationship to the shopwives, as we see in the following exchange:

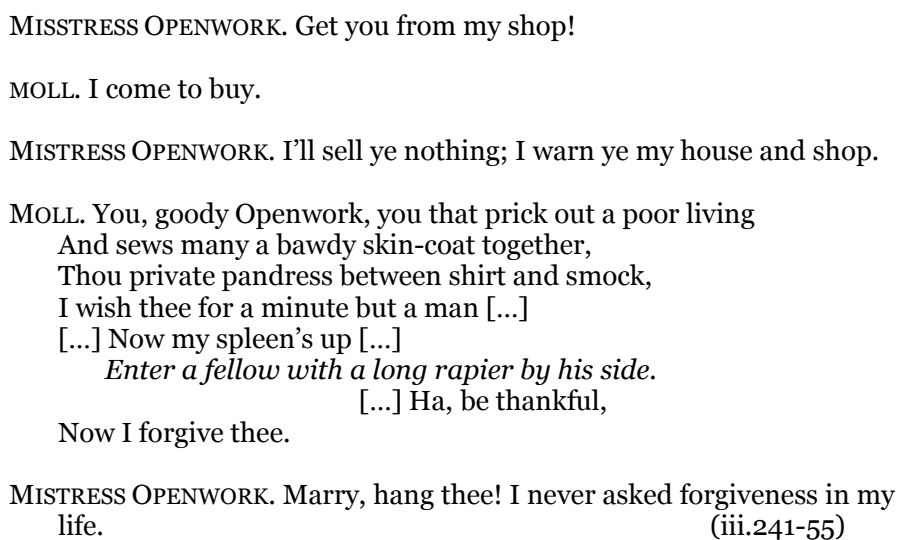

Moll challenges the Mistress through a surrogate, the "fellow" who "abused [her] t'other night in a tavern" (259-59). The Mistress's hostility toward Moll is born of sexual jealousy, provoked by her husband's offering Moll the "best in the shop" (231). The spatial and syntactical linkage of "house and shop" underscores the sexualization of the market-place in the play-indeed, the sub-plot is driven by the shop-wives' intrigues with the "gallants" whom they keep in fashion (not only by selling accessories like ruffs, but also by slipping them their husband's cash). Moll's counter-attack strategically impugns the

3 Coppélia Kahn, introduction to The Roaring Girl in The Collected Works, p. 721-78. All citations of the play will be from this edition and will be inserted in the text. 
Mistress's chastity, in a pre-emptive strike that betrays the heroine's own awareness of her reputation as a whore.

This instance of woman-to-woman hostility establishes one point of contrast with Sex and the City, as both the series and the film idealize female relationships (the book does not, but rather includes several verbally brutal cat-fights). Critics have pointed out the implausibility of this social harmony-particularly in a group of friends that includes such sexual diversity (Samantha, epitomizing the sexually aggressive "cougar," Charlotte the prude, and the other two vacillating in either direction between these poles). On the other hand, Moll's alleged whorishness does have a corollary in the characterization of the TV heroine. "Carrie Bradshaw knows good sex." The opening sequence of each episode reiterates this by way of an enormous image of Carrie in a sensual, reclining pose affixed to a city bus. Carrie's cougar-like glee in this ad-and, presumably, the fame it embodies-lasts only until the bus splashes her white tutu with New York puddle-slime. A metaphoric deflowering if I ever saw one.

Middleton and Dekker take pains to touch-up Moll's tarnished reputation: indeed, that is the play's defining purpose. Where New York douses Carrie in dirty water, Moll's "voice [...] drown[s] all the city" of London (iii.195-96). And when a gallant by the name of Laxton offers her money for sex, she draws her sword, throws his gold back at him with interest, and delivers the following oration:

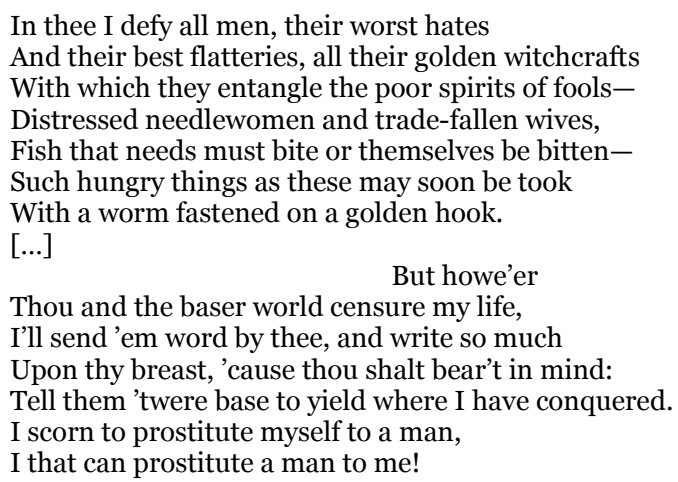

This speech-the longest in the play-stands alone in English Renaissance drama for laying bare the economics of prostitution, rather than simply demonizing "whores." Moreover, its imagery works 
in subtle ways to undermine phallocentrism and the sexual doublestandard. The "worm fastened on a golden hook" stands for the penisa suitably undignified image for a man named for his lacking masculinity (Lack-stone lacks a testicle) and in a play that complains that men are "shallow lechers" (3.330). The "golden hook" that lures the hungry fish to the otherwise unappetizing worm points up the play's gendering of money-and purses-as male, and echoes Laxton's own wish to "pierce through" a woman's hymen or chastity with a "golden auger" (3.203-4). The violence ricochets back at him, as Moll sends him offstage with a bloody warning to whore-mongers written on him with her phallic sword.

The delicious defiance of Moll's famous speech and her rousing sword-play in this scene might easily distract modern readers from a subtler source of her power. For her phallic potency lies not just in her breeches and not just in her sword, nor in any other cylindrical accessory about her (her pipe, her hat, her viol)-but in her purse. Purses nowadays are deeply gendered in the other direction, but a host of medieval and early-modern images associate this container with the scrotum. Laxton, lacking land and money, lacks the goods that define manhood in the play. It deserves note, for instance, that the money with which he tried to prostitute Moll he initially acquired from one of the shop-wives, who had filched it from her husband. Moreover, the gendering of money is underscored in a later scene when Moll receives coins "marked with holes" and hence invalid as currency (viii.211), visibly distinct from the intact equivalents and the pouch containing them-which was often worn at crotch-level. "Put money in your purse," Shakespeare's Iago advises a love-lorn Roderigo. ${ }^{4}$

Today men carry wallets. Discreet, flat, leather folios containing credit-cards, business-cards, bank-notes and perhaps a condom, to be slid inconspicuously into a back or breast-pocket. In my experience, coins rarely inhabit these receptacles, as a bulky wallet will distort the lines of a trouser pocket in a very unmanly way. If a man wants to make a point about his fiscal potency, he might simply do what Samantha's boyfriend does, tucking a phallic jewelry-case in his boxers, to be proffered in a private moment. However, a woman's purse-or rather

${ }^{4}$ William Shakespeare, The Tragedy of Othello, the Moor of Venice, in The Oxford Shakespeare, ed. Gary Taylor and Stanley Wells (Oxford, Clarendon Press, 1988), p. 81953. I quote 1.3.333. 
her "hand-bag"-is the sine-qua-non of her femininity and fashionsense, and the bulkier and better-labeled the better. In Sex and the City-above-all in the film-these objects are symbolically central. In contrast to the stream-lined and functional masculine wallet, these unwieldy and gaudy accessories are just that-accessories. To quote The Devil Wears Prada (2006)-a more intelligent example of the cinematic genre I think of as "city" chick fliks-"Fashion is not about utility. An accessory is merely a piece of iconography used to express individual identity." Indeed, the designer hand-bags so prominent on the elbows of chick-lit heroines like Carrie Bradshaw are not merely superfluous in our credit-based economy; they are fiscal liabilities, costing more than their monetary contents. Homes for manicured poodles, make-up cases, and cell-phones, these ungainly statusmarkers represent the triumph of consumerism over female freedom of movement.

In Sex and the City, one particular hand-bag practically upstages the character who carries it. Carrie's personal assistant, who arrives in New York jobless and looking for love, advertises this by wearing the word love on her key-chain. The expensive bag in which she carries that amulet prompts Carrie to ask her how she, an unemployed young black woman, could afford it. The answer: she has rented it. When her dream comes true and she prepares to leave town to marry Mr. Love, Carrie makes another dream come true, presenting her with a Louis Vuitton hand-bag. In response, the recipient of the bag squeals with delight and clutches it to her breast like a baby. The bag is empty in this scene, but it is heavy with symbolism: marriage, monogamy, maternity, all the "musts" of traditional femininity. Yes, the purse does bear a man's name (as would a baby), but that only underscores how the fetishization of designer labels mirrors the commodification of women. A woman's value in Carrie's world-no longer determined by the name that follows "Mrs."-is marked by the heraldry of a French hand-bag.

The imagery of bags underscores another cultural shift. The very title of the film and the cult manifests the comparative sexual freedom of what I'm calling the post-Cosmo generation. In a culture wherein childbearing no longer defines female productivity and social worth, what becomes crucial is the fruitfulness of this external pouchthat is, the purse's ability to reproduce itself in the more angular paper 
incarnations that we call shopping-bags. The movie does, of course, try to have it both ways in the conservative Charlotte. In the scene in which she berates Big for the wedding-day jilting, her hugely pregnant, polka-dotted belly vies with her bloated shopping-bags for the viewer's bemused attention. The clichéd comic business with the bags and the belly, upsetting dishes and silverware in an upscale restaurant, brings to its culmination a series of vignettes in which women are encumbered, immobilized, and/or humiliated in performing their gender. Charlotte goes into labor in this scene, thereby essentializing that immobility, but in other scenes it is a choice-for instance, Samantha's serving her lover a Valentine's Day dinner on her naked body (and then he doesn't show up to eat it), or Charlotte's ridiculous, mermaid-style, bridesmaid's gown, the ultimate in cartoonish and debilitating femininity.

The more we look at them, in fact, the less cougar-like-and more kittenish-these high-heeled pop-culture heroines begin to appear. I prefer the Renaissance counterpart-who had, in fact, some of the same sartorial choices. High heels did go in and out of fashion in early modern London-made of cork, and associated with "light" or wanton women. When Laxton calls "women [...] the best mincers" (iii.42), he suggests the prancing run-way walk of a fashionable lady on her high heels. Another of the gallants seems to fetishize these heels, spinning out the following sexual fantasy: "It's but liquoring them both soundly, and then you shall see their cork heels fly up high, like two swans, when their tails are above water and their long necks under water, diving to catch" fish (ix.85-89). The avian imagery puts a creative spin on the notion that these heels trip women up not just physically but sexually. Which is probably why Moll eschews such footwear along with the traditional, hampering petticoats. Indeed, you can plainly see Moll's flat-heeled shoes in the frontispiece to the playalong with her unfeminine "wide straddle" (v.186-87). Clearly, it is her masculine attire (along with, I imagine, the dexterity that makes her a kick-ass fencer) that allows her to slip "from one company to another like a fat eel between a Dutchman's fingers" (iii.213-14).

Moreover, Moll does not only avoid getting tripped-up: she seems to take pleasure in doing so to men. When dealing with Trapdoor-a rogue hired to kill her-Moll finds it easy (ironically, given his name) to bring him down: 
MoLL. What strength have you?

TRAPDOOR. Strength, Mistress Moll? I have gone up into a steeple and stayed the great bell as t'as been ringing; stopped a windmill going.

MOLL. And never struck down yourself?

TRAPDOOR. Stood upright as I do at this present.

Moll trips up his heels; he falls.

MoLL. Come, I pardon you for this; it shall be no disgrace to you. I have struck up the heels of the high German's size ere now. What, not stand?

TRAPDOOR. I am of that nature where I love, I'll be at my mistress' feet to do her service.

(iii.375-85)

The "high German" was a contemporary fencer, renowned for his height and strength, but seemingly no better a match for Moll than this Trapdoor at her feet, whose ineffectual snares she dodges throughout the play. In the last scene, however, she need not trip him; he voluntarily kneels. "Upon my paws I ask you pardon, mistress" (xi.232).

I have elsewhere written at length about Middleton's knack for applying bestial tropes to men as opposed to women, so I will only point out the canine (or feline) allusion here (one of many such in the play) and return to the contrast with Sex and the City, in particular the "happy ending," wherein Mr. Big winds up on his knees (if not his "paws") proposing marriage-again. ${ }^{5}$ Now those of you who haven't seen the movie might be wondering what brought this couple back together, after a cancelled wedding, a bridal-bouquet beating of the skittish bridegroom's head (no sword-play for Carrie), and a honeymoon-turned-all-girl-pity-party complete with margaritas and Montezuma's revenge. What brings Big and Carrie together in the film's climax is a pair of shoes. The shoes have been there, alongside the Louis Vuitton hand-bag, in the symbolic center of the film. In fact, the shoes have symbolized the cult of Sex and the City from the book's publication onward. Just as the mighty shopping-bag graces the cover of Confessions of a Shopaholic, so too do Carrie's fuck-me pumps

5 See Celia R. Daileader, "William Shakespeare, Thomas Middleton, and the Masculine Grotesque," in The Oxford Middleton Handbook, ed. Gary Taylor and Patricia Henley (Oxford, Clarendon Press, forthcoming). 
follow her from the cover of the best-seller to the film's fairy-tale finale. So despite Carrie's comment in the bed-time story scene, warning Charlotte's enraptured daughter that "Things don't always turn out" like they do in Cinderella, they do "turn out like that" for Carrie.

I do not need to belabor the symbolism of the stiletto heel. Like the lady's purse or hand-bag, these are concave, sexualized symbols, and their crippling effect on a woman's skeletal alignment is routinely belied in popular images that foreground the unlikely use of the pointy heel as a weapon. The feminist critique has done nothing, however, to diminish the cultural obsession with these objects. And so we are supposed to applaud Carrie for her heroism in rescuing her pumps from Big's closet. Should I say "Big's closet" or Carrie's? The penthouse apartment, of course, was his purchase-nor could the journalist heroine have afforded it (indeed, that is why she married him). But Big built the closet for Carrie and her clothes, in a moment that must have had Virginia Woolf rolling in her grave. Lucky girl! She marries a millionaire and gets a closet of her own! Pardon my sarcasm. I don't know why I expected more from the movie. And here a confession becomes necessary (confession being a staple of chick-lit). I was a fan of the series. In the early seasons, I found it smart, sexy, and irreverent. I did not imagine that this feisty, fiscally and intellectually independent woman columnist would regress from season to season, finally taking her exit in the stupefyingly clichéd cinematic finale, a self-doubting, shopaholic, shoe-worshipping urban wife. Why didn't they call the movie, "Kiss me, Carrie"?

In fact, the film has more in common with Shakespeare's Taming of the Shrew than Middleton and Dekker's city comedy. Moll, after all, exits stage just as she entered: defiantly and unambivalently single and self-supporting. By contrast, Carrie's happy ending raises questions about her future. Will she go on writing books about sex once she gets busy making baby Bigs? I for one am not fooled by his kneeling in the closet-scene, as he inserts Carrie's foot into a crippling, diamond-studded, Cinderella pump. Mr. Big has the bucks, and a marriage with him means he can call the shots. As his predecessor in the book growls, "I'm rich enough to have you followed." Moreover the girl-friends who tried to coax Carrie to eat when she shut herself in her honeymoon-suite won't be there if Big gets any Petrucchian big ideas.

\footnotetext{
${ }^{6}$ Candace Bushnell, Sex and the City (New York, Grand Central Publishing, 1997), p. 235.
} 
"Nay, stamp not, fret not, look not big," Shakespeare's hero warns his hungry bride, preparing to whisk her away from her wedding-feast. "I shall be master of my own./ She is my goods, my chattels, my field, my barn,/ My house, my household stuff, my horse/ My ox, my ass, my anything" (III.iii.100-103).

I am not excited about the prospect of a sequel to Sex and the City. Indeed, I don't know why they are making one. Judging from reviews, no one wants it. The New York Times on-line called the film "vulgar, shrill, and shallow"; weighing in at a hideous 145 minutes, it is "A dumpy big-screen makeover of that much-adored small-screen delight [... a film] awash in materialism and narcissism." Complaints about the length and the absurd amount of product-placement littered comments by critics and bloggers alike. "Too many plugs and too few sparks" complained the Telegraph. ${ }^{8}$ "I loved the series," reads one typical blog, "but this was more than a disappointment [...] it was slow, stupid and mind-numbing." One fan snipped, "Did I grow up, and they didn't?” Another groaned, "Horrible, horrible, horrible!” A male critic surrounded by euphoric fans at the London opening, "began to reason like one of the characters: maybe," he thought, "the problem was me. Everyone else, being in possession of more than one $\mathrm{x}$ chromosome, seemed entirely satisfied by what they were served." If loving this film defines one as a woman, though, you can start calling me hic mulier. I rather agree with a gay male blogger who called the film a "vile and retrograde label queen bonanza [...] a vulgar, dialogue-ridden commercial for designer labels [that] stretched needlessly beyond two hours [...] and the confines of any credible or enjoyable romanticism." The same blogger goes on, "The bitchy, insightful [...] chatter at upscale Manhattan coffee places [...] that [...] became the gorgeous trademark of the show has been rudely stripped from this long and tedious celluloid opus to the dollar [...] Sad, desperate for attention and botoxed to the gills, these gals offer a bleak and pricey prospect for American womanhood."

Even Samantha, the only one of the four who ends the film single, has been tamed. Though she accepts (on the condition that "It's a ring with diamonds, not a diamond ring”) the gift that pokes out of

\footnotetext{
${ }^{7}$ Manohla Dargis, “The Girls Are Back in Town”, The New York Times, February 15, 2010.

8 Sukhdev Sandhu, "Sex and the City: Too Many Plugs and Too Few Sparks" (The London Telegraph, May 28, 2008).
} 
her beau's underwear, she inexplicably bolts when her hunky neighbor beckons her-stark naked-to his outdoor shower. The last shot we see of her alone presents her compulsively gobbling chocolate mousse out of the hand of a beleaguered flight attendant, reduced to bingeing her way out of sexual famine. Cable TV's favorite cougar has been declawed.

On the other hand, though, this is Samantha at her most vulnerable and appealing, and the heavier incarnation of the character helped make up one of the few aspects of the film that critics admired: its honesty about ageing. And maybe the viewer discomfort can partly be linked to those conflicting moments of embarrassed identification (Charlotte's diarrhea, Samantha's weight-gain) and insulted incredulity over saccharine moments like the closet-scene. And here we arrive at an observation about genre. If city comedy's defining characteristic is its contemporaneity, its ability to bring real London street-life to the stage-as the Roaring Girl seems to have done when the real Moll Cutpurse mounted the stage at the Fortune Theatre-then its corollary in millennial popular culture would be the very antithesis of a Cinderella-story for forty-something females. And herein lies the problem with translating Sex and the City the series to the silver screen. It's not just that-as the New York Times complained-those "kooky and sometimes insanely unflattering" outfits looked better in miniature, but that Hollywood has a way of Disney-fying everything it gets its grubby hands on.

I return to my introductory comments about chick-lit and romance. What is the difference between these female-marketed genres? It's not that chick-lit is adverse to happy endings: after all, Bridget Jones's Diary re-tells Pride and Prejudice. But chick-litanyway, the best of it-grants its heroines a certain ironic detachment from the absurd mating rituals of urban professionals. When the aforementioned gay blogger praised the "bitchy, insightful [...] chatter" featured in the TV series, but absent from the film, he was touching on a key element of the show's appeal to feminists like myself. This is even more true of the novel, in which, for instance, Carrie, being told to put out her cigarette in a posh hotel, says, "Why, I wouldn't dream of offending anyone," and puts it out on the carpet.

I haven't talked about Carrie's quitting smoking, which is one of the many ways in which the series gradually tames her. As medically- 
incorrect as it may be to link smoking with empowerment, the Carrie who smoked shared at least that one indulgence with the original Renaissance cougar. Like her roaring, Moll's smoking allows her to take up social space. (Along these lines, I would point out that the campaign against smoking has largely harped on its effect on a woman's children-in utero and out-as in the warning label on my American-bought Capris, which makes no mention of smoking's ill effects on men, or women who are not pregnant and/or never wish to be.)

I hesitate to praise the female characters in Bushnell's novel, who are-without exception-soulless, greedy bitches. But there is something delicious to me about the image of a woman extinguishing a cigarette on the carpet under the nose of a snooty, five-star Maitre D. That may be the best thing done with women's footwear in popular culture since Nancy Sinatra's hit song "These Boots Were Made for Walking." I think of Moll Cutpurse's motto, "I please myself, and care not who else loves me" (10.361). But Moll is no bitch. And, far from soulless, she has "the spirit of four great parishes" (3.194-95). She may not carry a "love" key-chain, but she does believe in it: "Twixt lovers' hearts she is a fit instrument" (4.205). Indeed, Moll Flanders got a movie, why not our own "Mad Moll"-starring, perhaps, a more convincingly-butch Tilda Swinton.

Let the actress be forewarned, though. She has some big shoes to fill.

Celia R. DAILEADER

The Florida State University 